\title{
Dry Land Gull Colony
}

by Robert W. Nero, Univ. of Sask, Regina

The effect of drought conditions on wildlife is of considerable interest for by this means we gain some idea of the adaptability of species which presumably have survived numerous environmental changes during the past thousands of years. The case of Westerin Grebes adapting to changing water levels and an absence of emergent aquatic vegetation by nesting on dry land (Nero, Lahrman, and Bard, 1958. Dry-land nest-site of a Western Grebe colony. Auk, $75: 347-349)$ is a prime example. The widespread movement of waterfowl off the dry plains into the parklands and the recent increase in Lark Buntings in southern Saskatchewan are notable examples of shifts associated with drought conditions. This aspect of plains ornithology deserves careful study and should be of particular interest to residents of the plains.

The following notes are an attempt to document a report recently brought to my attention of a colony of Ring-billed Gulls (Larus dela- warensis) which was found in 1959 nesting on dry land which had formerly been an island in a slough near Kindersley, Saskatchewan. This account is based on photographs and notes supplied by Richard W. Fyfe and Fred W. Lahrman together with notes contributed by Dr. C. Stuart Houston and Glen A. Fox. Additional information was kindly provided by Herb Moulding, of Ducks Unlimited.

Lozinsky's slough is eight miles south and two miles west of Kindersley. During dry years its shallow basin has often been farmed for cereal crops. Run-off waters in most years have disappeared by fall but following very wet periods the slough has remained flooded for several successive years, and at times it has been a good breeding place for waterfowl. Records kept by Ducks Unlimited since 1942 show this slough carrying water in the years 1943, 1945, 1948 and 1951. In Saskatchewan 1952 was a big run-off year and the slough was full through 1955 when the water level
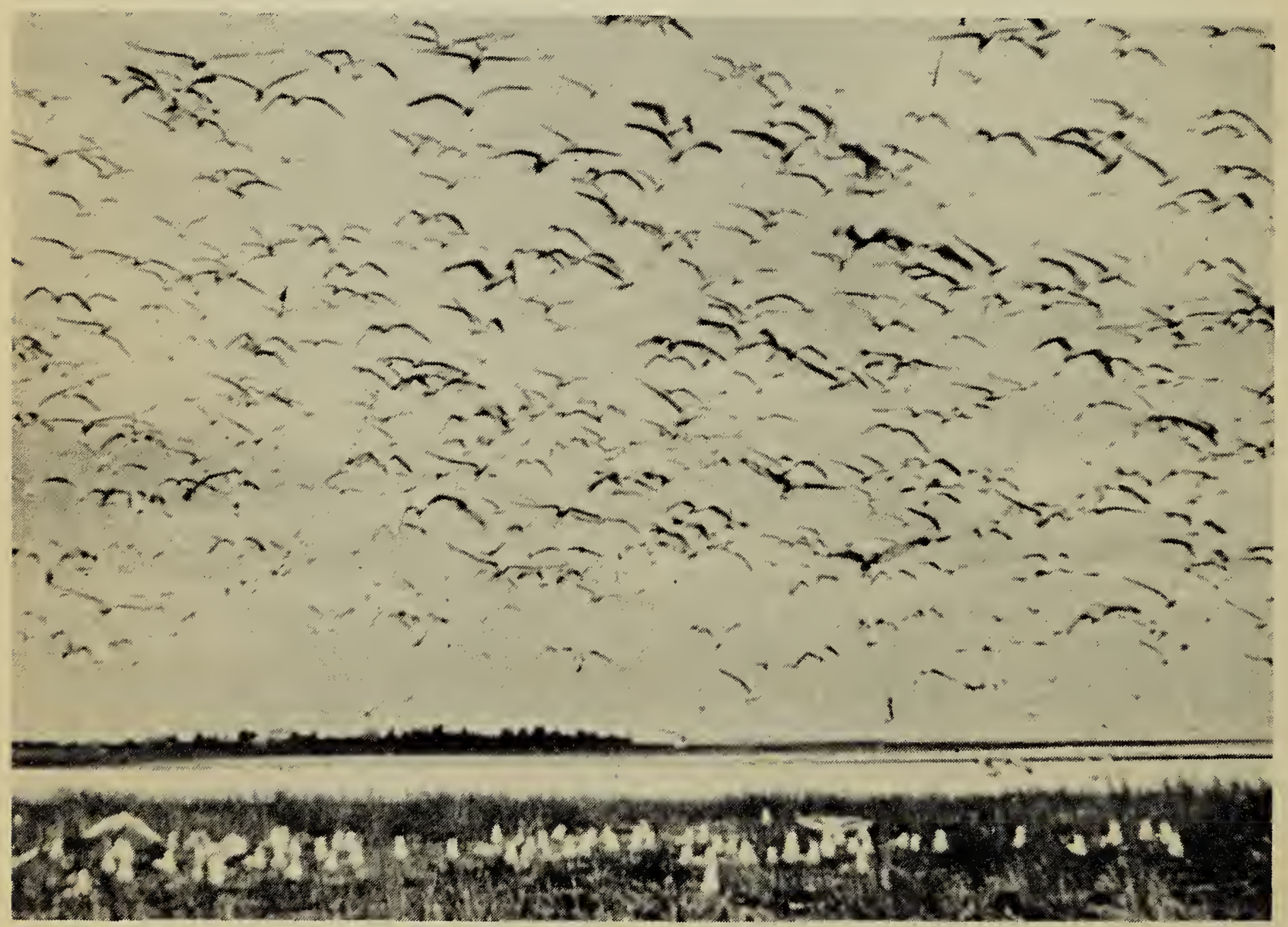

Fig. 1. Gull colony on island in Lozinsky's slough, 1955 or 1956.

Photo by R. W. Fyte 


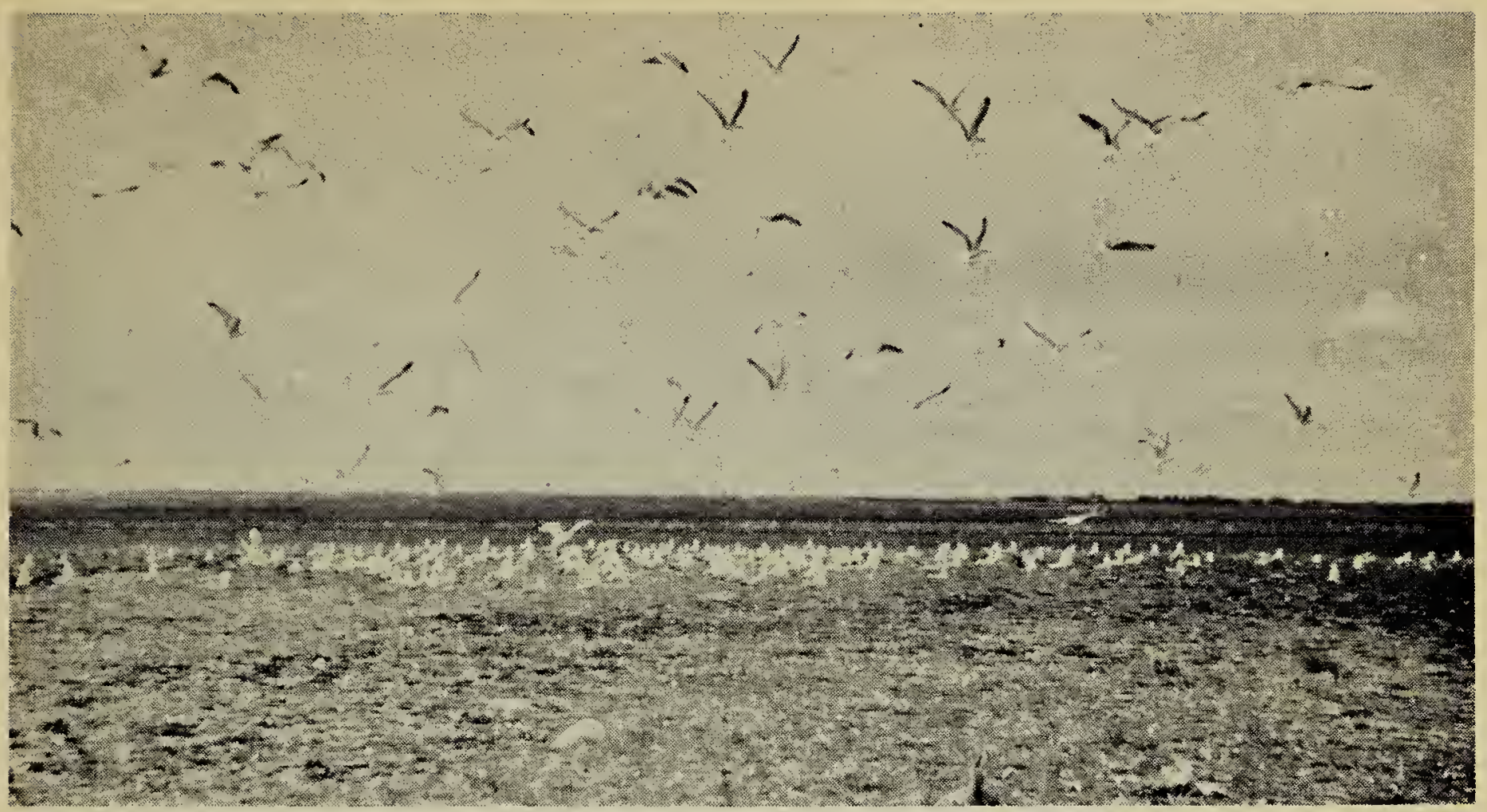

Fig. 2. Gull colony on island surrounded by cultivated land, June 7, 1959. Photo by F. W. Lahrman

began to fall. Gulls were present in 1955 (or 1956?) and nesting successfully on a small low island, according to Fyfe (see Fig. 1). Dr. Stuart Houston first visited the slough on June 25, 1957, when an estimated 1000 young gulls were present, comprised of 80 per cent Ring-billed Gulls and 20 per cent California Gulls (Larus californicus). Dr. Houston banded 385 immature gulls on that date. His second visit was made a year later on June 24, 1958, when there were an estimated 600 to 1000 young Ring-billed Gulls and 50 to 100 young California Gulls; 450 young gulls were banded by Houston, who noted very few Ringbilled Gull nests still with eggs, and only about 10 California Gull nests with two to four eggs. (Recoveries of these banded "Ringbills" have been made as far away as California and Mexico; "Californias" have also been recovered in Mexico - to December, 1960). Two censuses were made earlier in the year by Fox: on May 17, (1958) he estimated that there were present 2260 adult gulls and on May 24, an estimated 3414 adults, with 1429 active nests.

Further recession of water levels in 1958 (in June it was possible to wade to the island) led to cultivation of much of the land formerly under water, and by June 7, 1959, when Fyfe and Lahrman visited the site the colony was entirely surrounded by cultivated land (see Fig.
2). They found an active colony of gulls which was divided into three sections, with a well-beaten road leading to the colony and running between the two major sections. During the two hours of their visit ( $1: 00$ to $3: 00$ p.m. Sunday) about six cars drove out to the colony and the passengers, adult and young alike, toured the colony (see Fig. 3), causing considerable disturbance of the gulls. A local farmer reported that there had been traffic to the colony daily for some time. Estimates by Lahrman and Fyfe ran from 1075 to 2000 adult gulls, mainly Ring-billed Gulls, though both noted several breeding California Gulls (75 according to Fyfe). A single immature Herring Gull (Larus argentatus) which was seen with the California Gulls, was feeding on nests which contained both eggs and young, from hatching stage to about 10 days old. Many dead young were seen throughout the colony site.

Apparently, the gulls had returned to nest on the island in 1959 even though the water had already disappeared, for the land closely surrounding the former island, and even part of the island had been cultivated. Evidently only the area occupied by the gull colony had not been cultivated. An active Canada Goose (Brinta canadınsis) nest had earlier been moved by the landowner onto the "island" in order to permit closer cultivation - curiously, the 


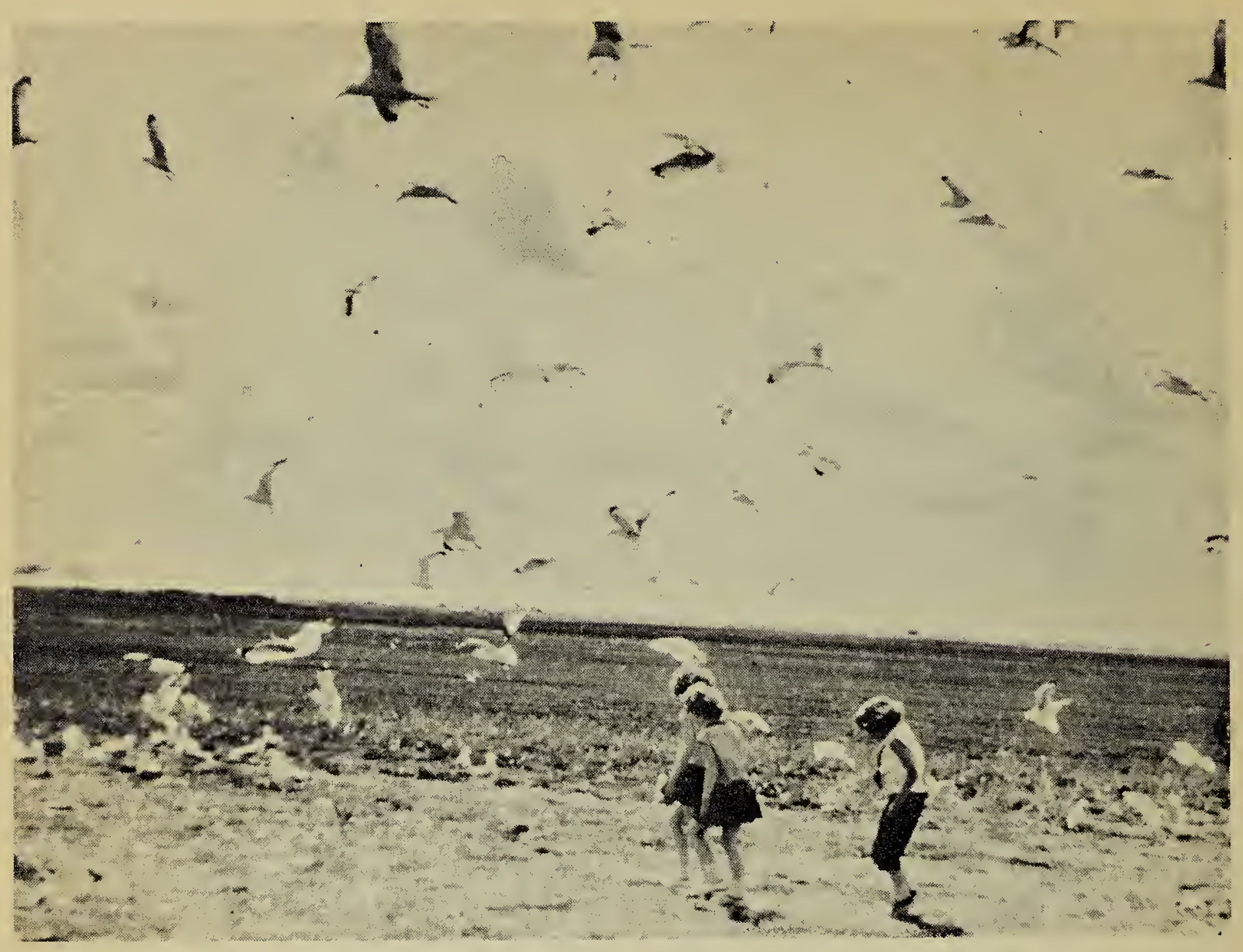

Fig. 3. Sunday visitors to a gull colony, June 7, 1959. Photo by R. W. Fyfe

goose returned to the nest at the new location and was still defying the visitors on June 7 . A considerable inconvenience, apart from the visitors, must have been experienced by the gulls nesting at this site, for the nearest water was a dug-out about two miles away and the nearest lake or marsh was no less than four miles distant. A later report received by Fyfe indicated that the colony had finally failed (by which I presume no young attained maturity), which is not surprising; but the extent to which the gulls persisted in the face of disturbance and lack of water is surprising.

Fox reported that he visited the site in the summer of 1960 when he found the slough dry again. A few gulls were seen in the vicinity but none were nesting. The island was later burned, in the course of which about three Canada Goose nests and three broods were destroyed, and finally the entire area was ploughed.

Island sites afford the maximum protection for colonial nesters, but such situations are not common on the plains. Hence, the capacity to find and use temporary island sites is probably an advantage.. Although under drought conditions reproductive success decreases and the colony may even break up, the high success obtained in good years may more than offset the loss. It would be useful to know where such populations breed in dry years. It seems reasonable to suppose that they move into northern regions; as do the waterfowl, and perhaps they may even move onto permanent islands, such as the Isle of Bays in Old Wives Lake, to join long-established populations. Fred W. Lahrman, upon query, stated that when he and Fred G. Bard visited the Isle of Bays in late May, 1961, they were both impressed by the increase in numbers of breeding Ring-billed Gulls and California Gulls. The latter species, especially, showed a marked increase; they had formerly occupied limited portions of the nesting area on the perimeter of the Ring-billed colony, but in 1961 a much larger area became available to them owing to an increase in the size of the nesting site as a result of low water level. 